\title{
Integrated and Site-Specific Fertilizer Application Role in Rice-Wheat Cropping System
}

\author{
Muhammad Akram Qazi ${ }^{1 *}$, Naveed Iqbal Khan', Farah Umar ${ }^{1}$, Ashfaq Ahmad Rahi², \\ Saima Nazar', Niaz Ahmed ${ }^{3}$, Abdul Ghaffar', Khalid Mehmood Mughal', \\ Imtiaz Ahmad Warraich', Zubaida Hamid', Mahreen Khalid', Umair Riaz ${ }^{1}$
}

${ }^{1}$ Soil Fertility Research Institute, Lahore, Agriculture Department, Punjab, Pakistan

${ }^{2}$ Pesticide Quality Control Laboratory, Multan

${ }^{3}$ Department of Soil Science Bahauddin Zakariya University, Multan, Punjab, Pakistan

Received: 25 May 2020

Accepted: 29 July 2020

\begin{abstract}
Continuous use of mineral fertilizers can worsen soil quality, leading to declining productivity and soil pollution. An effective integrated fertilizer strategy is required to help the agriculture cropping system to apply nutrients according to the site-specific need. Thus, to explore the role of application of site-specific and integrated nutrient management (INM), treatments containing 02 fertilizer doses and 03 management techniques for the application of soil organic matter (SOM), P \& K were studied in Punjab Pakistan's rice-wheat system. It is noted that the level of SOM can be improved by repeated application of the Municipal Solid Waste Compost (MSWC). INM treatments contributed a nonsignificant increase of $7 \%$ to $10 \%$ in the level of SOM relative to the initial level of $0.82 \%$. The target soil P level of $19.0 \mathrm{ppm}$ is achieved in this study by following a McLean model that is very close to the recommended $\mathrm{P}$ level of $21.0 \mathrm{ppm}$. There is also a decreasing trend in soil level $\mathrm{K}$ and negative balance K. Site-specific application of fertilizer envisages the superiority of $6.2 \%$ increase in soil P over conventional application in spite of the fact that the total site-recipe of $\mathrm{P}$ was $341.0 \mathrm{~kg} \mathrm{ha}^{-1}$ applied is very lower than conventionally applied $\mathrm{P}$ which was $600.0 \mathrm{~kg} \mathrm{ha}^{-1}$ in three years. Ranking of the best to the least favorable indices is documented as $\mathrm{P}>\mathrm{SOM}>\mathrm{K}$.
\end{abstract}

Keywords: integrated use, mineral fertilizers, INM, rice-wheat, site-specific, SOM

\section{Introduction}

Rice (Oryza sativa L.) - wheat (Triticum aestivum L.) is one of the world's largest agricultural production systems. Intensive farming techniques, unbalanced application of chemical fertilizers without proper

*e-mail: makramqazi@gmail.com review of soil nutrient status, poor soil management and high-yielding crop varieties have resulted in a substantial decrease in soil organic matter (SOM) and crop productivity over the past decades. [1, 2]. A useful strategy to feed the rapidly growing population is to increase the unit area production by using existing agricultural area and resources [3]. This can be accomplished by growing improved crop varieties [4], site specific way of fertilizer application [5], integrated 
nutrient management [6] and modified cropping systems [7]. But improved crop varieties require higher fertilizer doses as compared to conventional varieties, hence having an inherent disadvantage to degrade the quality of soil and cause eutrophication by phosphorus enrichment due to surface runoff [8-10]. [11] has described that use of mineral fertilizers continuously deteriorates the quality of soil and causing the soil pollution. Hence, to sustain a sustainable a cropping system, an effective and efficient fertilizer application as per need is required [12]. Soil test based fertilizer application can play a pivotal role due to its ability to determine fertilizer need for growing a crop [13]. The use of organic matter in the form of green manures [14], crop residues [15] and farmyard manure [16] has been conventionally used to maintain soil quality and to meet the requirements for crop nutrients. These Conventional sources are diminishing day by day due to their use in other purposes, mainly in energy [17]. Green manuring is also limited due to change of cropping pattern and intensive cultivation [18]. Other sources such as municipal solid waste compost (MSWC) application also attracted farmers and researchers by its high carbon content and ability to improve soil chemical and physical properties [19]. The idea of mixing organic , inorganic, and biological nutrient sources through Integrated Nutrient Management (INM) is being promoted as a way to increase the efficiency of nutrient use to meet crop demand [20, 21, 22]. To minimize the risk of harmful accumulations of heavy metals and phosphorus, it is not desirable to use compost as the sole nutrient for crop production [23]. Developing a well-balanced and integrated nutrient management plan that uses MSWC in conjunction with mineral fertilizers is therefore needed to enhance and maintain soil fertility [24] while reducing harmful environmental impacts. The indexation technique can be efficiently and effectively used to evaluate the effects of INM in a cropping system on the quality of soil and crop yield [25]. The present study in the rice-wheat cropping system of Punjab, Pakistan worked out to assess the cumulative effect of INM and site-specific application of fertilizer with and without use of pesticides and herbicides.

\section{Materials and Methods}

Field experiments on a permanent layout were conducted for six crop seasons in the rice-wheat cropping system in order to assess the effect of various applied treatments. Detail of the work plan is briefly given below;

\section{Site for Study on Rice-Wheat Cropping System}

Depending upon soil type and climate, different agricultural farming systems were established. The rice - wheat system is being practiced in the North Eastern areas of Punjab because the climate and soil type are favorable for cultivation of rice. To monitor and concede the system's effects on SOM, P and K, three years experimentation was conducted at Acre No. 8 of Adaptive Research Farm, Gujranwala, Punjab, Pakistan. Crops were irrigated with both canal as well as tube well water as per requirement. The experimental site $\left(32.19057^{\circ} \mathrm{N}\right.$ and $\left.74.18077^{\circ} \mathrm{E}\right)$ was under an ongoing rice-wheat cropping system.

\section{Treatments and Management Practices}

Three management techniques $\left(T_{-I}\right.$ : Only mineral fertilizer, $T_{-I I}$ INM of organic and mineral fertilizer in 1:4 along with application of pesticides and herbicides and $T_{-I I}$ : INM of organic and mineral fertilizer in 1:4 without application of pesticides and herbicides) and two mineral fertilizer doses ( $D_{-I}$ Conventional mineral fertilizer $\mathrm{P}$ application according to the current recommendation of the extension service without caring soil test value and $D_{-I I}$ : Site specific mineral fertilizer P application on soil test basis) were evaluated in the form of following combinations. Fertilizer doses were either based on standard N, P and $\mathrm{K}$ recommendations or on measured site-specific soil plant available phosphorus (PAP) levels. To understand, treatments are briefly detailed below:

\begin{tabular}{|c|c|c|}
\hline Treatment & Type & Description \\
\hline T-I X D-I & Conventional & $\begin{array}{l}\text { Conventional mineral fertilizer P application according to the current recommendation } \\
\text { of the extension service without caring soil test value }\end{array}$ \\
\hline T-I X D-II & Site specific & Site specific mineral fertilizer $\mathrm{P}$ application on soil test basis \\
\hline T-II X D-I & Conventional Organic & Conventional crop production with INM technique. \\
\hline T-II X D-II & INM & $\begin{array}{l}\text { INM of organic and mineral fertilizer in 1:4 on soil test basis along with application } \\
\text { of pesticides and herbicides. }\end{array}$ \\
\hline T-III X D-I & $\begin{array}{l}\text { Conventional Organic } \\
\text { without pesticides }\end{array}$ & $\begin{array}{c}\text { Conventional crop production with INM technique without application of pesticides and } \\
\text { herbicides. }\end{array}$ \\
\hline T-III X D-II & $\begin{array}{l}\text { INM without pesticide } \\
\text { use }\end{array}$ & $\begin{array}{l}\text { INM of organic and mineral fertilizer in 1:4 on soil test basis without application of } \\
\text { pesticides and herbicides }\end{array}$ \\
\hline
\end{tabular}


Table 1. Detail of MSWC application to soil.

\begin{tabular}{|c|c|c|c|c|c|c|c|}
\hline \multirow{3}{*}{$\begin{array}{l}\text { Combination } \\
\text { of Techniques } \\
\text { and Doses }\end{array}$} & \multicolumn{7}{|c|}{ MSWC Applied $\left(\mathrm{kg} \mathrm{ha}^{-1}\right)$} \\
\hline & Wheat-1 & Rice-1 & Wheat-2 & Rice-2 & Wheat-3 & Rice-3 & \multirow[b]{2}{*}{$\begin{array}{c}\text { Cumulative } \\
\text { Amount }\end{array}$} \\
\hline & $\begin{array}{l}\text { Soil test } \mathrm{P} \text { at } \\
\quad \text { sowing } \\
=8.2 \mathrm{mg} \mathrm{kg}^{-1}\end{array}$ & $\begin{array}{l}\text { Soil test } \mathrm{P} \text { at } \\
\text { transplanting } \\
=18.4 \mathrm{mg} \mathrm{kg}^{-1}\end{array}$ & $\begin{array}{c}\text { Soil test } \mathrm{P} \text { at } \\
\quad \text { sowing } \\
=14.6 \mathrm{mg} \mathrm{kg}^{-1}\end{array}$ & $\begin{array}{l}\text { Soil test } \mathrm{P} \text { at } \\
\text { transplanting } \\
=17.8 \mathrm{mg} \mathrm{kg}^{-1}\end{array}$ & $\begin{array}{c}\text { Soil test } P \text { at } \\
\quad \text { sowing } \\
=16.7 \mathrm{mg} \mathrm{kg}^{-1}\end{array}$ & $\begin{array}{l}\text { Soil test } \mathrm{P} \text { at } \\
\text { transplanting } \\
=14.7 \mathrm{mg} \mathrm{kg}^{-1}\end{array}$ & \\
\hline $\begin{array}{c}T_{-I} X D_{-I} \quad \text { and } \\
T_{-I} X D_{-I I}\end{array}$ & 0 & 0 & 0 & 0 & 0 & 0 & 0 \\
\hline $\begin{array}{c}T_{-I I} X D_{-I} \text { and } \\
T_{-I I} X D_{-I}\end{array}$ & 4000 & 4000 & 4000 & 4000 & 4000 & 4000 & 24000 \\
\hline $\begin{array}{c}T_{-I I} X D_{-I I} \text { and } \\
T_{-I I I} X D_{-I I} \\
\end{array}$ & 3200 & 1200 & 2800 & 1600 & 2000 & 2800 & 13600 \\
\hline
\end{tabular}

Table 2. Mineral fertilizer application rates.

\begin{tabular}{|c|c|c|c|c|c|c|c|}
\hline \multirow{3}{*}{ Crop detail } & \multirow{3}{*}{$\begin{array}{l}\text { Soil P } \\
(\mathrm{ppm})\end{array}$} & \multicolumn{6}{|c|}{ Mineral Fertilizer Application Rate $\left(\mathrm{kg} \mathrm{ha}^{-1}\right)$} \\
\hline & & \multicolumn{3}{|c|}{$D_{-I}$ (Conventional) } & \multicolumn{3}{|c|}{$D_{-I I}($ Site Specific) } \\
\hline & & $\mathrm{N}$ & $\mathrm{P}_{2} \mathrm{O}_{5}$ & $\mathrm{~K}_{2} \mathrm{O}$ & $\mathrm{N}$ & $\mathrm{P}_{2} \mathrm{O}_{5}$ & $\mathrm{~K}_{2} \mathrm{O}$ \\
\hline Wheat, $1^{\text {st }}$ Crop & 8.7 & 135 & 100 & 40 & 135 & 80 & 40 \\
\hline Rice, $1^{\text {st }}$ Crop & 18.4 & 115 & 100 & 40 & 115 & 30 & 40 \\
\hline Wheat, $2^{\text {nd }}$ Crop & 14.6 & 135 & 100 & 40 & 135 & 73 & 40 \\
\hline Rice, $2^{\text {nd }}$ Crop & 17.8 & 115 & 100 & 40 & 115 & 37 & 40 \\
\hline Wheat, $3^{\text {rd }}$ Crop & 16.7 & 135 & 100 & 40 & 135 & 49 & 40 \\
\hline Rice, $3^{\text {rd }}$ Crop & 14.7 & 115 & 100 & 40 & 115 & 72 & 40 \\
\hline \multicolumn{2}{|c|}{ Total } & 750 & 600 & 240 & 750 & 341 & 240 \\
\hline
\end{tabular}

\section{Application Rates of MSWC}

The MSWC was prepared aerobically by M/S Waste Busters Pvt Ltd. Lahore, Punjab, Pakistan. MSWC application was made on the basis of the $P$ requirement of a crop in a treatment. A computed quantity of MSWC was integrated in respective fertilizer dose in 1:4 (MSWC: Mineral fertilizer) on the soil test P basis. [26] emphasized phosphorus based application rather than nitrogen based application of compost in order to avoid loading of contaminants particularly phosphorus. In Punjab, Pakistan, the P sufficiency soil level (Olsen sodium bicarbonate extractable) was recommended as $21 \mathrm{ppm}$ [27]. The MSWC analysis depicted that it contained organic matter $40 \%$, nitrogen \& phosphorus $5.0 \mathrm{ppm}$ and potassium $10.0 \mathrm{ppm}$, zinc $2.0 \mathrm{ppm}$, copper $0.5 \mathrm{ppm}$, Iron $20.0 \mathrm{ppm}$, manganese $1.0 \mathrm{ppm}$, lead $0.1 \mathrm{ppm}$, Nickle $0.05 \mathrm{ppm}$, cobalt $0.05 \mathrm{ppm}$, cadmium $0.05 \mathrm{ppm}$ and chromium $0.05 \mathrm{ppm}$. The MSWC application to each treatment in every season is presented in Table 1. and Initial soil characteristics is given in Table 2. A McLean prediction model for site specific $\mathrm{P}$ application was followed by McLean, et al., 1982 [28].

\section{Mineral Fertilizer Application Rates}

The detail of mineral fertilizers applied in permanent field during three years in six crop seasons are given in Table 2.

\section{Analysis of Soil Characteristics}

The following methods were used for analysis of SOM, $\mathrm{P}$ and $\mathrm{K}$.

\begin{tabular}{|c|c|c|}
\hline Sr. No. & Parameter & Method Followed \\
\hline 1. & SOM & {$[29]$} \\
\hline 2. & Soil Phosphorus & {$[30]$} \\
\hline 3. & Soil Potassium & {$[31]$} \\
\hline 4. & $\begin{array}{c}\text { Phosphorus and } \\
\text { in kg hal }\end{array}$ & $\begin{array}{c}\text { P or K balance }=\sum \text { (Fertilizer } \\
\text { P or K, municipal solid waste } \\
\text { manure P or K, irrigation } \\
\text { water P or K) - Plant P or K } \\
\text { (P or K removal by grain and } \\
\text { straw) }\end{array}$ \\
\hline
\end{tabular}


Table 3. Initial soil characteristics.

\begin{tabular}{|c|c|c|c|c|c|c|c|c|c|}
\hline Depth & $\mathrm{EC}$ & $\mathrm{pH}$ & $\mathrm{OM}$ & $\mathrm{P}$ & K & Sand & Silt & Clay & \multirow{2}{*}{ Textural Class } \\
\hline $\mathrm{Cm}$ & $\mathrm{dS} \mathrm{m}^{-1}$ & - & $\%$ & \multicolumn{2}{|c|}{ ppm } & \multicolumn{3}{|c|}{$\%$} & \\
\hline $0-15$ & 1.3 & 7.9 & 0.82 & 8.7 & 119 & 43.6 & 37.2 & 19.2 & Loam \\
\hline $15-30$ & 1.4 & 8.0 & & 9.3 & 115 & 47.6 & 34.0 & 18.4 & Loam \\
\hline
\end{tabular}

P fixation factor $=2.5$

\section{Indexation}

The indices were calculated in respect of SOM, $P$ and $K$. The index value of each characteristic of a cropping system was determined as the ratio the improved characteristic to that of conventional characteristic. For example the index of the SOM was determined as "SOM because of INM/SOM due to only mineral fertilizer application".

If the value of the index is more than one indicates positive role/effect, if the value of the index is less than one indicates a negative role/effect and if the value of the index is equal to one indicates no change as described by Eltun et al., 2002 [32].

\section{Design and Analysis}

A combination of techniques and doses effect was studied on SOM, P \& $\mathrm{K}$ in the rice-wheat system by considering as one unit and the unit was replicated thrice in a split plot design by using statistical software "CoStat 6.451".

\section{Results and Discussion}

The results of field experiments for six seasons are discussed hereafter according to treatment effect on SOM, Phosphorus, and Potassium.

\section{Changes in Soil Organic Matter (SOM)}

Total application of MSWC was 14.0 tons ha-1 and 24.0 tons ha $^{-1}$ (Table 1) during three years in applied treatments resulted in 7.3 to 9.8 percent increase in SOM over an initial level of $0.82 \%$ to a level of $0.90 \%$ by management techniques $\left(T_{-I I}\right.$ and $\left.T_{-I I I}\right)$ through inclusion of MSWC with and without pesticide use (Table 4). The only mineral fertilizer application in $T_{-I}$ also increased $3.7 \%$ SOM. The performance of $T_{-I I}$ and $T_{-I I I}$ over $T_{-I}$ is $5.9 \%$ and $3.5 \%$ respectively in enhancing SOM level. While, conventional $\left(D_{-I}\right)$ and Site-specific $\left(D_{-I I}\right)$ doses enhanced SOM level $6.1 \%$ and $8.5 \%$ respectively. Sitespecific $\left(D_{-I I}\right)$ dose performed $2.3 \%$ better in enhancing SOM level as compared to conventional $\left(D_{-I}\right)$. By season's interpretation, maximum increase of $26.8 \%$ in SOM was observed after the harvest of the first rice crop and $6.1 \%$ at the harvest of final rice crop.
The impact of the season is substantially different in different crop seasons. It was also found that initial significant improvement in SOM was first rice harvest, then decreased or sustained status. But in all seasons, values were higher than initial (Table 4). It counts high attainment that the increase in SOM was taken place in an exhaustive cropping system of semi-arid to arid climate especially through INM. Rate of increase of SOM over the initial level in six crop seasons after crop harvest is depicted in (Table 4).

\section{Changes in Soil Phosphorus}

The marked beneficial effects of MSWC application on STP level were observed in this system. Statistical significant improved soil test phosphorus (STP) level was observed by the site-specific way of fertilizer application $\left(D_{-I I}\right)$ over the conventional fertilizer application $\left(D_{-I}\right)$ after three years (Table 4). The conventional $\left(D_{-I}\right)$ and site-specific $\left(D_{-I I}\right)$ doses enhanced soil test phosphorus (STP) level $85.1 \%$ and $96.6 \%$ respectively over initial level. Comparison of two doses revealed that $6.20 \%$ increase was due to site-specific way of fertilizer application over conventional fertilizer application (Table 4) in spite of the fact site-specific way of fertilizer application received less i.e. $\mathrm{P}_{2} \mathrm{O}_{5}$ i.e. $341 \mathrm{~kg} \mathrm{ha}^{-1}$ as compared to conventional fertilizer application which received $\mathrm{P}_{2} \mathrm{O}_{5}$ i.e. $600 \mathrm{~kg} \mathrm{ha}^{-1}$ in three years (Table 2). Total application of MSWC was 14-24.0 tons ha-1 (Table 3) during three years in INM techniques resulted in $88.5 \%$ to $97.7 \%$ increase in STP over an initial level of $8.70 \%$ to a level of $16.40 \mathrm{ppm}$ and $17.2 \mathrm{ppm}$ by both management techniques $\left(T_{-I I}\right.$ and $\left.T_{-I I I}\right)$ of INM with and without pesticide use (Table 4). The only mineral fertilizer application in $T_{-I}$ also increased $86.2 \%$ STP level. By season's interpretation, $86.2 \%$ increase in STP level was observed after the harvest of the final rice crop (Table 4). It is important to note that season's effect is significantly different in different crop seasons. It was also noticed that initial significant improvement in STP level was at first wheat harvest, afterwards status was almost remained sustained. It counts significant attainment that the increase in STP level was taken place in an exhaustive cropping system of arid to semiarid climate, especially through site-specific way of fertilizer application and INM. [33] claimed that Soil available $\mathrm{P}$ concentration and $\mathrm{P}$ uptake were 
Table 4. Soil OM, P and K status after three years of experimentation.

\begin{tabular}{|c|c|c|c|c|c|c|}
\hline Treatments & SOM (\%) & $\begin{array}{l}\text { \% Increase over } \\
\text { initial SOM level } \\
\quad(0.82 \%)\end{array}$ & $\mathrm{P}_{2} \mathrm{O}_{5}(\mathrm{ppm})$ & $\begin{array}{c}\text { \% Increase over } \\
\text { initial STP level } \\
(8.7 \mathrm{ppm})\end{array}$ & $\begin{array}{c}\mathrm{K}_{2} \mathrm{O} \\
(\mathrm{ppm})\end{array}$ & $\begin{array}{l}\% \text { Increase over } \\
\text { initial soil K level } \\
(119 \mathrm{ppm})\end{array}$ \\
\hline \multicolumn{7}{|c|}{ Fertilizer doses } \\
\hline$D_{-I}$. Conventional & $0.87 \mathrm{a}$ & 6.1 & $16.1 \mathrm{~b}$ & 85.1 & $107 \mathrm{a}$ & -10.1 \\
\hline$D_{-I I .}$ Site-specific & $0.89 \mathrm{a}$ & 8.5 & $17.1 \mathrm{a}$ & 96.6 & $107 \mathrm{a}$ & -10.1 \\
\hline LSD .05 & 0.043 & & 0.89 & & 4.7 & \\
\hline$\%$ increase over $D_{-r}$ & 2.3 & & 6.2 & & 0.0 & \\
\hline \multicolumn{7}{|c|}{ Management Techniques } \\
\hline$T-I$. Only Mineral fertilizer & $0.85 \mathrm{a}$ & 3.7 & $16.2 \mathrm{a}$ & 86.2 & $106 \mathrm{a}$ & -10.9 \\
\hline T-II. INM with pesticides & $0.90 \mathrm{a}$ & 9.8 & $16.4 \mathrm{a}$ & 88.5 & $104 a$ & -12.6 \\
\hline T-III. INM without pesticides & $0.88 \mathrm{a}$ & 7.3 & $17.2 \mathrm{a}$ & 97.7 & $110 \mathrm{a}$ & -7.6 \\
\hline LSD .05 & 0.053 & & 1.09 & & 5.7 & \\
\hline$\%$ increase in $\mathrm{T}_{-I I}$ over $\mathrm{T}_{-I}$ & 5.9 & & 1.2 & & -1.9 & \\
\hline$\%$ increase in $\mathrm{T}_{-I I I}$ over $\mathrm{T}_{-I}$ & 3.5 & & 6.2 & & 3.8 & \\
\hline \multicolumn{6}{|c|}{ Season } & \\
\hline Wheat, $1^{\text {st }}$ Crop & $0.76 \mathrm{~d}$ & -7.3 & $18.4 \mathrm{ab}$ & 111.5 & $105 \mathrm{c}$ & -11.7 \\
\hline Rice, $1^{\text {st }}$ Crop & $1.04 \mathrm{a}$ & 26.8 & $14.1 \mathrm{~d}$ & 62.1 & $124 b$ & 4.2 \\
\hline Wheat, $2^{\text {nd }}$ Crop & $0.95 b$ & 15.9 & $17.1 \mathrm{bc}$ & 96.6 & $140 \mathrm{a}$ & 17.6 \\
\hline Rice, $2^{\text {nd }}$ Crop & $0.84 \mathrm{~cd}$ & 2.4 & $16.2 \mathrm{c}$ & 86.2 & $105 \mathrm{c}$ & -11.8 \\
\hline Wheat, $3^{\text {rd }}$ Crop & $0.82 \mathrm{~cd}$ & 0 & $14.5 \mathrm{~d}$ & 66.7 & $91 d$ & -23.5 \\
\hline Rice, $3^{\text {rd }}$ Crop & $0.87 \mathrm{c}$ & 6.1 & $19.3 \mathrm{a}$ & 121.8 & $76 \mathrm{e}$ & -36.1 \\
\hline LSD .05 & 0.08 & & 1.45 & & 7.6 & \\
\hline
\end{tabular}

Figures sharing same alphabet are not significantly different from each other

affected significantly by the addition of P-enriched compost. Rate of increase of STP level over initial level in six crop seasons after crop harvest is depicted in (Table 4).

\section{Changes in Soil Potassium}

No beneficial effects of MSWC application regarding the soil $\mathrm{K}$ level were observed in the rice-wheat system. Statistically non-significant decrease in the soil K level was observed by the site-specific way of fertilizer application $\left(D_{-I I}\right)$ over the conventional fertilizer application $\left(D_{-I}\right)$ after three years. The conventional $\left(D_{-I}\right)$ and site-specific $\left(D_{-I I}\right)$ doses decreased soil K level by $10.1 \%$ over the initial level (Table 4). Total application of MSWC was 14-24.0 tons ha-1 during three years in INM techniques resulted in decrease soil $\mathrm{K}$ level by $12.6 \%$ and $7.6 \%$ over an initial level of $119 \mathrm{ppm}$. A decrease of $10.9 \%$ in soil $\mathrm{K}$ level was observed by technique of only mineral fertilizer application $\left(T_{I}\right)$. A significant declining trend is visible in seasons. By season's interpretation, overall 36.1\% decrease in the soil $\mathrm{K}$ level was observed after the harvest of final rice crop. Probably the K additions were not adequate to meet the enhanced crop's requirement. [34] also reported continuous mining of $\mathrm{K}$ in the soils of Punjab, Pakistan.

In neighboring Punjab, India, the depletion of essential nutrients, especially $\mathrm{P}$ and $\mathrm{K}$, triggered low yield of rice and wheat. In a long-term rice-rice-wheat network trial, long-term FYM application will increase exchangeable K [35]. Potassium showed a negative apparent balance ranging from 52.2-181.5 kg K/ha/year with a mean of $134.52 \mathrm{~kg} \mathrm{~K} / \mathrm{ha} /$ year and recommended the combined use of organic manure, where available, with inorganic fertilizers for yield trends and nutrient budgeting under long-term (28-year) nutrient management in the rice-wheat crop system. [36]. As regards potassium, a significant declining trend is noted in the seasons after $2^{\text {nd }}$ wheat crop harvest (Table 4).

\section{Indexation of Soil Organic Matter, Phosphorus, and Potassium}

Soil fertility characteristics play a vital role in the sustainability of a farming system. Values of SOM 
Table 5. Mean indices of soil fertility indicators.

\begin{tabular}{|c|c|c|c|c|}
\hline $\begin{array}{c}\text { Technique } \\
\text { / Dose }\end{array}$ & $\mathrm{SOM}$ & $\mathrm{P}_{2} \mathrm{O}_{5}$ & $\mathrm{~K}_{2} \mathrm{O}$ & Mean \\
\hline$T_{-I}$ & 1.086 & 1.167 & 1.002 & 1.085 \\
\hline$T_{I I}$ & 1.012 & 1.018 & 0.962 & 1.000 \\
\hline$T_{-I I I}$ & 1.072 & 1.030 & 1.044 & 1.048 \\
\hline$D_{-I I}$ & 1.042 & 1.063 & 0.999 & 1.034 \\
\hline Mean & 1.049 & 1.069 & 1.002 & 1.040 \\
\hline
\end{tabular}

and soil nutrients status are recorded with improved practices as well as with conventional practices over the whole study period were used as indices of soil fertility and these indices are listed in Table 5. Indices ranking of the best to least favorable were recorded as $\mathrm{P}>\mathrm{SOM}>\mathrm{K}$. Comprehensive mean soil fertility index was estimated as 1.040. No negative effect was found. Favorable mean indices were achieved using techniques $T_{-1}$, followed by $\mathrm{T}_{-I I I}$ compared to $\mathrm{T}_{-I I}$. Mean index 1.085 and 1.048 of $T_{-I}$ and $T_{-I I I}$ respectively was based on favorable values of $\mathrm{P}$ and SOM and incorporation of MSWC in fertilizer recipes contributed in enhancing their status. In another technique $\left(T_{-I I}\right)$, the $\mathrm{SOM}$ index was not promising. Here, SOM status seems to be suppressed may be due to the application of herbicides and non-target effect of herbicides used by the elimination of flora [37, 38, 39]. Enrichment of SOM seems to be the residual effect of the flourished roots due to the availability of nutrients applied through mineral fertilizers. The findings supported the conclusions of [40]. The degrading effects of a cropping system due to soil fertility depletion cannot be mitigated without introduction of new improved technique like INM with cost-effective organic sources and less herbicides/pesticide use to protect/sustain SOM. Positive site specific P dose $\left(D_{-I I}\right)$ index (improved practice over conventional routine) i.e. 1.034 was noticed primarily due to favorable indices of $\mathrm{P}$ and SOM. Indices of Potassium indicated no change and it lowered down the ultimate mean value of the index for improved fertilizer dose prediction.

\section{Conclusions}

Total application of MSWC was 14.0 tons ha-1 and 24.0 tons $\mathrm{ha}^{-1}$ during three years resulted in 7.3 to 9.8 percent increase in SOM over an initial level of $0.82 \%$ through INM in rice-wheat cropping system. The season's effect was significantly different in different crop seasons. Statistical significant improved soil test phosphorus (STP) level was observed by the site-specific way of fertilizer application over conventional fertilizer application after three years. The conventional and sitespecific doses enhanced soil test phosphorus (STP) level $85.1 \%$ and $96.6 \%$ respectively over initial level of $8.7 \mathrm{ppm}$. Both techniques of INM with and without pesticide use resulted in $88.5 \%$ to $97.7 \%$ increase in STP over an initial level. The target soil P level of $19.0 \mathrm{ppm}$ is recorded by following a McLean's model which is closed to recommended level of $21.0 \mathrm{ppm}$ although some variations are recorded in different seasons. The $\mathrm{K}$ application either through INM or through mineral fertilizers did not increase the soil test $\mathrm{K}$ level and overall $36.1 \%$ decrease in the soil $\mathrm{K}$ level was observed after the harvest of final rice crop. Probably the $\mathrm{K}$ additions were not adequate to meet the enhanced crops requirement in rice-wheat cropping system. Indices ranking from the best to least favorable were recorded as $\mathrm{P}>\mathrm{SOM}>\mathrm{K}$.

\section{Conflict of Interest}

The authors declare no conflict of interest.

\section{References}

1. SAHAA P.K., ISHAQUEB M., SALEQUEB M.A., MIAHB M.A.M., PANAULLAHB G.M., BHUIYANB N.I. Long-term integrated nutrient management for ricebased cropping pattern: effect on growth, yield, nutrient uptake, nutrient balance sheet, and soil fertility. Commun Soil Sci Plan. 38, (5-6), 579, 2007.

2. QAZI M.A., AKRAM M., AHMAD N., ARTIOLA J.F., TULLER M. Economical and environmental implications of solid waste compost applications to agricultural fields in Punjab, Pakistan. Waste Manage. 29, 2437, 2009.

3. MESGARAN M.B., MADANI K., HASHEMI H., AZADI P. Iran's Land Suitability for Agriculture. Sci. Rep. 7, 7670, 2017. https://doi.org/10.1038/s41598-017-08066-y.

4. CLARKE N., BIZIMANA J.C., DILE Y., WORQLUL A., OSORIO J., HERBST B., RICHARDSON J.W., SRINIVASAN R., GERIK T.J., WILLIAMS J. Evaluation of new farming technologies in Ethiopia using the Integrated Decision Support System (IDSS). Agric. Water Manag. 180, 267, 2017.

5. CHATHURIKA S.P., INDRARATNE, DANDENIYA W.S. Site Specific Fertilizer Recommendations for Maize (Zea mays L.) Grown in Reddish Brown Earth and Reddish Brown Latasolic Soils J.A.S. J. Sustain. Trop. Agric. Res. 25 (3), 287, 2014

6. KHAN M.N., MOBIN M., ABBAS Z.K., ALARI S.A. Fertilizers and their contaminants in soils, surface and groundwater. Encyclopedia Anthropocene 5, 225, 2018.

7. URAYAMA H., TAKAMA H., MARUYAMA S. Economic Feasibility of Coconut Coir-Based Hydroponics as an Alternative System for Crop Management in Thailand. J Sustain Agr. 12, 45, 2017.

8. CHANDINI R.K., RAVENDRA K., PRAKASH O.M. The Impact of Chemical Fertilizers on our Environment and Ecosystem. In book: Research Trends in Environmental Sciences, Edition: 2nd, Chapter: 5, 69, 2019.

9. SHARPLEY A., JARVIE H.P., BUDA A., MAY L., SPEARS B., KLEINMAN P. Phosphorus legacy: Overcoming the effects of past management practices to mitigate future water quality impairment. J. Environ. Qual. 42, 1308, 2013. 
10. ABERA T., DEBELE T., WEGARY D. Effects of Varieties and Nitrogen Fertilizer on Yield and Yield Components of Maize on Farmers Field in Mid Altitude Areas of Western Ethiopia. Int. J. Agron. 1-13, 2017. DOI: $10.1155 / 2017 / 4253917$

11. JAT L.K., SINGH Y.V., MEENA S.K., PARIHAR M., JATAV H.S., MEENA R.K., MEENA V.S. Does integrated nutrient management enhance agricultural productivity? J. Pure Appl. Microbiol. 9 (2), 1211, 2015.

12. SHARMA A., CHETANI R. A Review on the Effect of Organic and Chemical Fertilizers on Plants. International Journal for Research in Applied Science \& Engineering Technology (IJRASET), 677, 2017.

13. KAUSAR R., AZAM M., NAWAZ S., AHMAD I., IQBAL N. Indexing soil fertility status and suitability of groundwater in Sargodah district. J. Environ. Agric. 1 (1), 12,2016

14. TIMSINA J. Can organic sources of nutrients increase crop yields to meet global food demand? AGRON J. 8, 214, 2018.

15. HIEL M., BARBIEUX S., PIERREUX J. Impact of crop residue management on crop production and soil chemistry after seven years of crop rotation in temperate climate, loamy soils. Peer J, 6, e4836, 2018.

16. GUO L.Y., WU G.L., LI Y., LI C.H., LIU W.J., MENG J., LIU H.T., YU X.F., JIANG G.M. Effects of cattle manure compost combined with chemical fertilizer on topsoil organic matter, bulk density and earthworm activity in a wheat-maize rotation system in Eastern China. Soil Till. Res. 156, 140, 2016.

17. CHERUBIN M.R., OLIVEIRA D.M.S., FEIGL B.J., PIMENTEL L.G., LISBOA I.P., GMACH M.R., VARANDA L.L., MORAES M.C., SATIRO L.S., POPIN G.V., PAIVA S.R., SANTOS A.K.B., VASCONCELOS A.L.S., MELO P.L.A., CERRI C.E.P., CERRI C.C. Crop residue harvest for bioenergy production and its implications on soil functioning and plant growth: a review, Sci. Agric. 75, 255, 2017.

18. VINOD K., SINGH B.S., DWIVEDI R.P., MISHRA A.K., SHUKLA J.T., PRAVIN K., UPADHYAY K.S., KAUSHIK M., AZAD S.P. Yields, Soil Health and Farm Profits under a Rice-Wheat System: Long-Term Effect of Fertilizers and Organic Manures Applied Alone and in Combination. AGRON J. 8, 1, 2018.

19. MEENA M.D., NARJARY B., SHEORAN P., JAT H.S., JOSHI P.K., CHINCHMALATPURE A.R., YADAV G., YADAV R.K., MEENA M.K. Changes of phosphorus fractions in saline soil amended with municipal solid waste compost and mineral fertilizers in a mustard-pearl millet cropping system. Catena, 160, 32, 2018. doi.org/10.1016/ j.catena.2017.09.002.

20. GRAHAM R., WORTMAN S., PITTELKOW C. Comparison of Organic and Integrated Nutrient Management Strategies for Reducing Soil $\mathrm{N}_{2} \mathrm{O}$ Emissions. Sustainability, 9, 510, 2017.

21. WU W., MA B. Integrated nutrient management (INM) for sustaining crop productivity and reducing environmental impact: A review. Sci. Total Environ. 512, 415, 2015.

22. JAT L.K., SINGH Y.V., MEENA S.K., MEENA S.K., PARIHAR M., JATAV H.S., MEENA R.K., MEENA V.S. Does integrated nutrient management enhance agricultural productivity? J. Pure Appl. Microbiol. 9 (2), 1211, 2015

23. YANG X., LI, Q., TANG Z., ZHANG W., YU G., SHEN Q., ZHAO F. J. Heavy metal concentrations and arsenic speciation in animal manure composts in China. Waste Manag. 64, 333, 2017.

24. KHALIL A., QADIR G., NAWAZ M.Q., SAQIB A.I., RIZWAN M., ZAKA M.A., REHIM A., IMRAN M., BASHIR M.A. Integrated Phosphorus Management Improves Production of Rice-Wheat Cropping-System Under Salt Affected Conditions. Int. J. Plant Prod. 12, 25, 2018.

25. ANDREWS S., MITCHELL S., MANCINELLI J.P.R., KARLEN D.L., HARTZ T.K., HORWATH W.R., PETTYGROVE G.S., SCOW K.M., MUNK D.S. On-farm assessment of soil quality in California's Central Valley. Agron. J. 94, 12, 2002.

26. CHOWDHURY R.B., MOORE G.A., WEATHERLEY A.J., ARORA M. Key sustainability challenges for the global phosphorus resource, their implications for global food security, and options for mitigation. J. Clean. Prod. 140, 945, 2017.

27. AKRAM M., MIAN S.M., AHMAD Z., GILL K.H. Use of fertilizer phosphorus at sufficiency level to sustain soil fertility without environmental repercussions. Pak. J. Soil Sci. 18, 19, 2000.

28. MCLEAN E.O., OLOYA T.O., MOSTAGHIMI S. Improved fertilizer recommendations based on twostep alternative usage of soil tests; I. Recovery of soil equilibrated phosphorus. Soil Sci. Soc. Amer. J. 46, 1193, 1982.

29. WALKLEY A., BLACK C.A. An estimation of Degtareff methods for determining soil organic matter and a proposed modification of the chromic acid titration method. Soil Sci. 37, 29, 1934.

30. OLSEN S.R., SOMMERS L.E. Phosphorus. In. A.L. Page et al. (ed.). Methods of Soil Analysis. Part 2. $2^{\text {nd }}$ ed. Agron. Monogr. 9. ASA and SSSA, Madison, WI. 403, 1982.

31. BROWN J.R., WARENCKE D.D. Recommended cation tests and measures of cation exchange capacity. In: Recommended chemical soil test procedures for North Central Region. Bull. No. 499. (ed.) W.C. Dahnke, 15-16 North Dakota Agric. Exp. Stn., Fargo, ND. 1988.

32. ELTUN R., KORSÆTH A., NORDHEIM O. A comparison of environmental, soil fertility, yield, and economical effects in six cropping systems based on an 8-year experiment in Norway. 90, 155, 2002.

33. MAJEED A., MEHDI S.M., NIAZ A., MAHMOOD A., UL-HAQ E., AHMAD N., JAVID S., MEHMOOD A. Influence of P-enriched compost application on economics and $\mathrm{P}$ use efficiency of a maize-wheat rotation system. J. Crop Prod. 6 (6), 651, 2018.

34. WAKEEL A., REHMAN H., MAGEN H. Potash Use for Sustainable Crop Production in Pakistan: A Review. Int J Agric Biol. 19 (3), 2017

35. RAWAL N., GHIMIRE R., DEVRAJ C. Crop Yield and Soil Fertility Status of Long Term Rice-RiceWheat Cropping Systems. Indian J Biotechnol. 5 (1), 42, 2017.

36. DAS A., SHARMA R.P., CHATTOPADHYAYA N., RAKSHIT R. Yield trends and nutrient budgeting under a long term (28 years) nutrient management in rice-wheat cropping system under subtropical climatic condition. Plant Soil Environ. 60 (8), 351, 2014.

37. GIESY J.P., DOBSON P., SOLOMON K.R. Eco toxicological Risk Assessment for Roundup Herbicide. 35120, 2000.

38. SEBIOMO A., OGUNDERO V.W., BANKOLE S.A. Effect of four herbicides on microbial population, soil organic 
matter and dehydrogenase activity. Afr J Biotechnol 10, 770, 2012.

39. RIAH W., LAVAL K., LAROCHE-AJZENBERG E., MOUGIN C., LATOUR X., TRINSOUTROT-GATTIN I.
Effects of pesticides on soil enzymes: a review. Environ. Chem. Lett. 12, 257, 2014.

40. SINGH B., RYAN J. Managing fertilizers to enhance soil health. IFA, Paris, France, 2015. 